\title{
Dzieło jako proces. Wokół spójności tekstów Tadeusza Różewicza
}

Utwory literackie Tadeusza Różewicza sprawiają wrażenie otwartych, nietrwałych, labilnych. Autor w miarę rozwoju swojej twórczości coraz bardziej je przetwarza, publikuje $w$ różnych wersjach i konfiguracjach, niekiedy w dwu kolejno wydawanych tomikach; czasem uwzględnia w nowszym zbiorze swój dawny wiersz, odnawiając jego sensy w otoczeniu innych utworów, a w końcowej fazie twórczości umieszcza w obrębie jednego tomu dwa warianty jednego tekstu, publikując jego zachowaną na faksymile wersję rękopiśmienną. Późne zwłaszcza wiersze Różewicza są zatem otwarte w tym sensie, że nie zamykają się w jednej formie, którą można by uznać za ostateczną.

Są również otwarte w innym znaczeniu - wykraczania poza stylistyczne i gatunkowe ramy języka literackiego. Różewicz zaczyna z czasem coraz częściej wypełniać swoje utwory materią cudzego słowa, fragmentami gazet czy audycji oraz wycinkami innego rodzaju pozaartystycznych wypowiedzi. Przetwarza je przy tym tak, by zachowywać ślady ich źródłowego pochodzenia. Pozornie nieasymilowane, wymieszane z fragmentami, które sprawiają wrażenie odautorskich wypowiedzi, wyrażanych serio, bez intencji polemicznej czy parodystycznej, tworzą efekt nieopracowanego brulionu, pełnego zasłyszanych $w$ radiu czy przepisanych z gazety luźnych notatek.

Przypatrując się natężeniu tych zjawisk, można dostrzec w późnej twórczości Tadeusza Różewicza dominację dwu strategii tekstotwórczych: pierwsza polega na eksponowaniu procesualności tworzenia, druga - na literackim recyklingu, czyli eksperymentalnym, krytycznym przetwarzaniu języka nieartystycznego. Samo pojęcie recyklingu (zapisywanego zresztą przez poetę w wersji niespolszczonej, jako recycling) Różewicz usankcjonował

\footnotetext{
*Instytut Badań Literackich PAN, e-mail: marta.bukowiecka@ibl.waw.pl.
} 
jako składnik własnej poetyki, odnosząc się do niego w tytule tomiku zawsze fragment. recycling.

\section{Tekst bez granic}

Znaczenia w utworach Różewicza formują się nie tyle w obrębie pojedynczego tekstu, ile między różnymi jego wariantami, a także - między mową zaczerpniętą z codziennej logosfery a jej literacką transformacją, a więc znaczące są tu i teksty, i łączące je relacje. Otwierając kompozycję swoich utworów, zarówno w znaczeniu zacierania ich formalnych granic, jak i otwierania twórczości na pozaartystyczną mowę, Różewicz projektuje lekturę wielokierunkową, skontekstualizowaną, równoległą i zespajającą rozproszone w całym dorobku wersje utworu w jedną złożoną całość. Jest to lektura łącząca przetworzoną poetycko wypowiedź nieliteracką z jej oryginałem czy możliwą do wyobrażenia wersją pierwotną. Oznacza to, że autor sankcjonuje swój otwarty warsztat pracy nad tekstem jako metaliteracki problem, przedmiot reprezentacji i zarazem integralny składnik dzieła literackiego, a samo dzieło traktuje jako dynamiczny proces, a nie strukturę zamkniętą w scalających utwór formach. Można je tu rozumieć rozmaicie: jako większe struktury dzieła literackiego, takie jak rodzaj i gatunek; jako porządki, w których może funkcjonować utwór, a więc konwencje czy style; i wreszcie - jako ramy najbardziej ogólne, które wyznacza granica tekstu. W miarę rozwoju twórczości Różewicza rozmywa się nawet ta najbardziej podstawowa dla literatury kategoria: tekst traci swoje granice.

To zagadnienie otwiera wiele pytań: co stanowi o literackości tekstu, jeśli nie scalające go ramy gatunku literackiego ani jednolitość stylu artystycznego? Czy utwór literacki może funkcjonować jedynie jako zamknięta, odrębna, autonomiczna całość? W jakim sensie i zakresie może ewoluować w jednostkowym dorobku? Jeśli istnieje w wielu wariantach, czy można jeden z nich uznać za kanoniczny? Skoro czytelnik ma dostęp do kilku wersji jednego tekstu, zwłaszcza jeśli niektóre publikowane są jako faksymile rękopisu, to w jakim sensie może uznać się za świadka procesu twórczego? Czy możliwe jest w tej sytuacji ustanowienie granicy między procesem twórczym a jego efektem? A jeśli utwór nie tylko zmienia swoją postać w kolejnych tomikach, ale - widziany odrębnie - zdaje się co więcej urywać wpół słowa - jak wtedy zakreślić jego granice? Jaki jest wobec tego formalny i semantyczny zakres spójności tekstu? A może raczej: tekstów? Nie wyznacza go również najogólniej pojęta forma książki, skoro niektóre tomiki Różewicza to odmiennie skomponowane układy tych samych wierszy. I nawet polszczyzna nie jest językowym uniwersum, ogólnym porządkiem tej twórczości, skoro w jej późnej fazie pojawia się sporo tekstów niemieckich: czy to nietłumaczonych cytatów w obrębie jednego utworu (na przykład $\mathrm{w}$ poemacie recycling $\mathrm{w}$ tomie zawsze fragment. recycling), czy całych cudzych tekstów wmontowanych do tomiku (przykładem może tu być niemiecki wiersz zapisany czcionką gotycką w tomiku Kup kota w worku), 
czy przekładów wierszy autorskich (tomik Nauka chodzenia. Gehen lernen ma strukturę lustrzaną, co zresztą zapowiada sam tytuł. Każdy polski wiersz ma swój niemiecki odpowiednik).

Jeśli sens utworu kryje się nie tylko w jego ramach, ale wynika z porównania kilku wariantów jego zapisu, nie zawsze łączonych w jednym tomie, i ze skojarzenia literackich transformacji mowy nieartystycznej ze wzorcem jej pierwotnego użycia, można uznać, że obszarem spajającym czy formującym ich znaczenia jest cały dorobek Różewicza. Nie tylko dlatego, że stanowi nadrzędny porządek różnych form zapisu wiersza, pozwalający dostrzec w nich kilkuelementową całość, ale też z tego względu, że na tym szeroko zarysowanym tle rozproszone metaliterackie uwagi, wciąż powtarzane w utworach publikowanych w różnych okresach, tworzą razem spójną, całościową koncepcję literatury, w której elementy obce mowie poety tłumaczą się jako tworzywo parodystycznych transformacji czy przedmiot krytycznego odniesienia, a nie formułowane serio elementy własnych wypowiedzi pisarza.

Utwory Różewicza, choć luźno skomponowane i otwarte na zmiany, jawią się jako elementy spójnego porządku. Warto je odnieść do (przywołanych przeze mnie dalej) teoretycznych koncepcji spójności tekstu literackiego i na tym tle ujawniać ich transgresyjny charakter. Reguły koherencji - które według Marii Renaty Mayenowej wyznacza lingwistyczny charakter tekstu pojmowanego jako suma linearnie przyrastających zdań, a zgodnie z koncepcją Włodzimierza Boleckiego struktura dzieła literackiego, znacząca jako układ relacji między jego poziomami - w twórczości Różewicza nie konstytuują się ani w obrębie zdania, ani pojedynczego dzieła, lecz w sferze intertekstualnej łączącej zarówno warianty utworów Różewicza, jak i jego teksty z powstałymi uprzednio wypowiedziami. O spójności decyduje w tym przypadku nie kompozycja utworu, ale podobieństwo cech łączące kilka jego wersji (lub łączące fragment wypowiedzi literackiej z jej wariantem źródłowym).

Znaczenie równoległego publikowania wierszy może z kolei uświadomić (również zarysowany niżej) teoretyczny kontekst założeń krytyki genetycznej, szkoły badawczej skupionej na analizie znaczeń, które wynikają z porównania różnych postaci jednego tekstu. Wydobywane przez badaczy z pisarskich szuflad, w twórczości Różewicza zostają ujawniane przez samego autora, stają się tematem literackiego przedstawienia, a tym samym prowokują do pytań o znaczenie samego dzieła literackiego i kontekstu, w jakim się znalazło. Jako przykład tej zależności mógłby posłużyć utwór Opowiadanie dydaktyczne, czytany w tomiku zawsze fragment. W tym kontekście tworzy inne znaczenia niż wtedy, gdy jest odniesiony do wersji publikowanej czterdzieści lat wcześniej w zbiorze Nic w płaszczu Prospera; wiersz usytuowany w dwóch poetyckich kontekstach znaczy wszakże co innego. Tym sposobem można odnieść utwór do zatytułowanych podobnie Opowiadań dydaktycznych, które wbrew kwalifikacji gatunkowej wpisanej w tytuł stanowią trzy krótkie sekwencje prozy włączone jako całość do zbioru Uśmiechy (by skomplikować sprawę, kilkakrotnie wznawianego 
i przetwarzanego) - i pytać o związki między równie "myląco" nazwanym wierszem i fragmentem prozy. Albo: o przyczynę, dla której Opowiadanie dydaktyczne znika z tomiku zawsze fragment. recykling, złożonego $\mathrm{w}$ większości z wierszy publikowanych dwa lata wcześniej w tomie zawsze fragment. Wszystkie potencjalne znaczenia wynikłe z tego porównania uświadamia kontekst całego dorobku.

Jego znaczenie, a także zmienny charakter utworów Różewicza omówili badacze tej twórczości. Tomasz Kunz rozpatruje (wśród wielu innych zagadnień) problem ich konstrukcji w odniesieniu do całego dorobku, rozumianego ,jako przekaz wielotekstowy, którego poszczególne elementy ujmowane są w sposób synchroniczny, a więc w kategoriach systemu, w którym wariantowe realizacje stanowią zawsze część struktury odsłaniającej wzajemne napięcia, relacje i funkcjonalne współistnienie poszczególnych składników"1. . Nie mniej liczą się w niej również widoczne ślady zaniechania, uznane przez Kazimierza Wykę za równoprawne elementy ponadformalnej struktury zamiennika gatunkowego, zasadniczej dla opisu procesualnie ujmowanego dzieła literackiego Różewicza. Mówiąc ściślej, oznacza on

określony ciąg wydarzeń rozgrywających się w obrębie warsztatu pisarskiego i owego ciągu nieoczekiwany, a domagający się wyjaśnienia rezultat końcowy. Wspomniane wydarzenia rozgrywają się w trójkącie między trzema wierzchołkami: intencja (zamierzenie) twórcza; realizacja (wykonanie) zamierzenia; rozmycie (infiltracja) pierwotnego zamierzenia przez realizację. Ten dopiero końcowy rezultat domaga się w wypadku Różewicza osobnej nazwy: zamiennik, zastępnik².

Potrzeba przedefiniowania pojęć literaturoznawczych w odniesieniu do poetyki Różewicza wzięła się z przekonania, że - jak pisze Wyka - „dorobek tego autora nie daje się rozłożyć na siatce gotowych i dotąd uprawianych gatunków literackich" ${ }^{3}$. Utwór rozpatrywany jako wypadkowa zamierzenia, wykonania i infiltracji pierwotnego założenia ujawnia inne sensy niż wtedy, gdy jest traktowany wyłącznie jako efekt pracy twórczej. Na przykład opowiadanie Śmierć w starych dekoracjach z punktu widzenia jego genezy jest zamiennikiem $\mathrm{w}$ stosunku do nienapisanej sztuki pod tym tytułem ${ }^{4}$. Z kolei utwór Przyrost naturalny, rozpatrywany w kontekście autorskiej intencjonalności, jawi się jako nienapisana komedia, zastąpiona swoją „,biografią”, na którą złożył się opis życia pisarza, jego pamiętnik intelektualny oraz dziennik nienapisania utworu ${ }^{5}$.

${ }^{1}$ T. Kunz, Strategie negatywne w poezji Tadeusza Różewicza. Od poetyki tekstu do poetyki lektury, Kraków 2005, s. 169.

${ }^{2}$ Tamże, s. 92.

${ }^{3}$ K. Wyka, Problem zamiennika gatunkowego, [w:] tegoż, Różewicz parokrotnie, oprac. M. Wyka, Warszawa 1977, s. 91.

${ }^{4}$ Tamże.

${ }^{5}$ Tamże. 
Przyrost łączy, co więcej, nie tylko cechy różnych gatunków, ale i kilka tematów odmiennej wagi. Fragmenty opisu codziennej krzątaniny, którą wypełniają zasłyszane $\mathrm{w}$ radiu informacje i zwyczajne błahe czynności („Wstaję. Zapalam światło”) przeplatają się z wyznaniami niemocy twórczej autora czy koncepcjami teoretycznymi, istotnymi dla analizy całej jego twórczości; warto tu przywołać zwłaszcza tę: „dla mnie zagadnieniem nie jest «początek», «środek» i domniemany «koniec» dramatu, ale trwanie pewnej sytuacji [...] dopiero u Becketta jesteśmy świadkami nie tylko pozornej akcji, ale i rozkładu tej akcji na scenie... ten rozkład jest u niego akcją" ${ }^{6}$. Podobne deklaracje uświadamiające konsekwencję formowania spójnej koncepcji literatury w całym okresie twórczym Różewicza odnaleźć można w tekstach podejmujących różnorodną tematykę, powstałych na przestrzeni wielu lat. $\mathrm{Na}$ przykład w ostatnim tomiku z 2012 roku, to $i$ owo, pojawia się taki fragment:

czytanie przepisywanie

poprawianie i czytanie

milczenie i wściekłość

odczytywanie

to jest właśnie „zawód”

pisarza poety $\mathrm{i}$

literata $^{7}$

Pięćdziesiąt lat wcześniej, w tomiku Zielona róża, autor prezentował tę samą procesualną koncepcję dzieła literackiego w wierszu Propozycja druga:

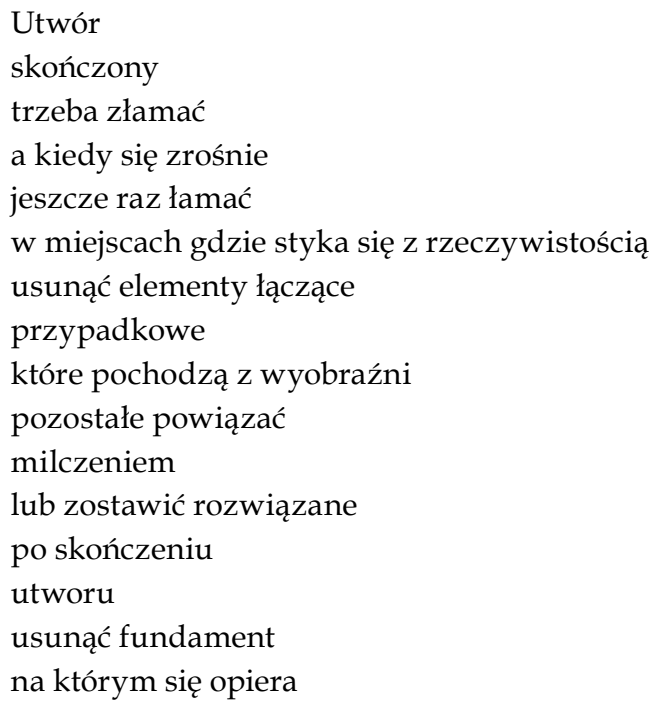

${ }^{6}$ T. Różewicz, Przyrost naturalny. Biografia sztuki teatralnej, [w:] tegoż, Dramat. Utwory zebrane, t. II, Wrocław 2005, s. 129.

${ }^{7}$ T. Różewicz, zawód: literat, [w:] tegoż, to i owo, Wrocław 2012, s. 7. 


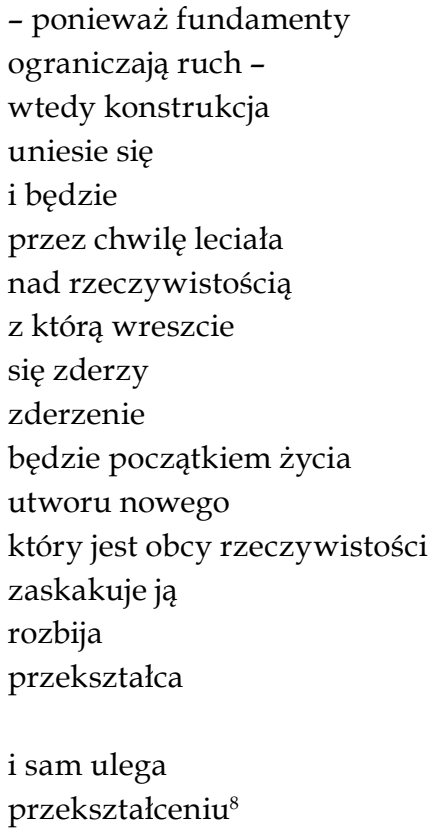

\section{Zużyte słowa}

Innym przykładem podobnego wiązania sensów rozproszonych w całej twórczości Różewicza jest utwór Tarcza z pajęczyny z 1962 roku9 . Widziany jako odrębna całość (luźno przy tym skomponowana i niedomknięta) przypomina kolaż wielu „pre-tekstów”"10, wypowiedzi już-gotowych, wyjętych z realnego kontekstu pragmatycznego i użytych w funkcji poetyckiej jako literackie ready-mades; Tarcza łączy zręby wielu gatunków oraz strukturalne cechy poezji i prozy. Siłą rzeczy teksty już-gotowe, w wersji fragmentarycznej i niepełnej włączone do utworu, nie zamykają się w stabilnych i trwałych ramach, choć jednocześnie widoczne w nich ślady porządków, do których pierwotnie należały, wskazują metonimicznie na odrzucone struktury, konwencje i normy. Utwór, co więcej, łączy na prawach groteski treści poważne i błahe, wiele z nich przetwarza, ucina czy synkretyzuje, a im więcej głosów nakłada na siebie nadrzędny podmiot tej wielorodnej narracji, tym bardziej zaciera ich tematyczną, podmiotową czy formalną wyrazistość i autonomię.

Warto je odczytywać w możliwie najszerzej zakrojonym kontekście, który ujawnia status kilku pomniejszych tekstów budujących tę większą

${ }^{8}$ T. Różewicz, Poezja. Utwory zebrane, t. II, Wrocław 2006, s. 201-202.

${ }^{9}$ Ten utwór analizuję bardziej szczegółowo i pod innym kątem w tekście „Tarcza z pajęczyny" z daleka i z bliska. Intertekstualność kolażu literackiego, [w:] Projekt na daleką metę. Prace ofiarowane Ryszardowi Nyczowi, red. Z. Łapiński, A. Nasiłowska, Warszawa 2016.

${ }^{10}$ Pojęcie Włodzimierza Boleckiego, por. tegoż, Pre-teksty i teksty. Z zagadnień związków międzytekstowych w literaturze polskiej XX wieku, Warszawa 1998. 
całość. W wielorodnym kolażu notek prasowych znalazły się fragmenty autorskich tekstów, niepodpisane nazwiskiem poety i niewyodrębnione z narracji Tarczy jako całości pełniące wcześniej funkcję odrębnych utworów literackich. Tym samym zostają one zrównane $\mathrm{z}$ formami nieaktualnej informacji dziennikarskiej, potraktowanej jako materia literacka, i wtapiają się we wtórnie utworzoną wielorodną narrację. Można dostrzec w tym zabiegu większy metaliteracki zamysł radykalnego odrzucenia idei poetyckiej swoistości i odrębności, a także kolejną w twórczości Różewicza formę deprecjonowania własnego słowa, która wpisuje się $\mathrm{w}$ antyromantyczną wizję poety opisującego sprawy ostentacyjnie zwyczajne.

Siedzę teraz w zamkniętym pokoju [...]. Jestem pracowity i obowiązkowy. W ciemności bije zegar. Na wieży. „Wypełniam swój obowiązek”. Oczywiście to jeszcze jeden utarty zwrot który zginie kiedyś razem z ludzkim gatunkiem. Nie wcześniej i nie później. Przecież ten dzień w którym wszyscy ludzie zostali zwolnieni ze swych obowiązków już był. Datę trudno ustalić ale wiemy o tym. Jednak pielęgniarka kapitan okrętu górnik lekarz strażak „poeta”... Jednak wszyscy zostali na swoich posterunkach. Nawet „poeta” już dawno żywcem pogrzebany poprawia tekst wiersza. Raz drugi trzeci dziesiąty. Skreśla przymiotniki. Człowiek współczesny jest ruchomy i otwarty ${ }^{11}$.

Oto poeta (a nawet "poeta") widzi siebie jako ostatniego w szeregu przeciętnych. Nie jest ponad nikim ani nawet wśród innych, lecz jakby pod ziemią: "trzeba się uspokoić poeto poeci pismo poetyckie / kryzys poezji współczesna poezja klub poetów / krypta kret metafora", w zmartwiałym podziemiu drąży tunele; tym jest zapewne dla niego mozolne skreślanie przymiotników, poprawianie wiersza "raz drugi trzeci dziesiąty".

Podobne autoopisy powracają często w literackim dorobku Różewicza; zwykle odnoszą się do wertykalnie wartościowanej przestrzeni, w której miejsce poety wyznaczone jest przez niego samego zawsze na dole. $\mathrm{W}$ tym fragmencie podmiot mierzy się z mitem poetyckiego natchnienia przeciwstawionego mozolnej fizycznej pracy, którą w podobnych opisach Różewicz wiąże na ogół z materią ruin, fundamentów, śmieci, odpadków:

na mnie wiersz

nie spada

jak światło na

Szawła

ani gołębica

ja wiersz

buduję

od fundamentów

${ }^{11}$ T. Różewicz, Tarcza z pajęczyny, [w:] tegoż, Proza. Utwory zebrane, t. I, Wrocław 2003, s. 225-226. 
ruiny

ruiny $^{12}$

W Opowiadaniu dydaktycznym pojawia się z kolei postać „poety chmur”, który wciela tradycję wysokoartystycznego, natchnionego pisania, choć owe „chmury" nasuwają też skojarzenia ze zgoła niepoważnym bujaniem w obłokach. Tymczasem, pisze poeta,

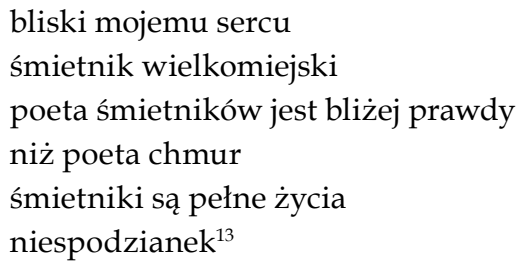

Pojęcie śmietnika i bliska mu recyklingowa technika obróbki ma w tej twórczości, jak się wydaje, wiele znaczeń. Powtórne przetwarzanie „śmietnikowej” materii słowa - czyli tej, którą „poeta chmur” spisałby na straty jako nieważną, błahą, niegodną poezji, bo pozaliteracką - dotyczy zasadniczo języka wypowiedzi dziennikarskich. Poeta odnosi się do nich rozmaicie; niektóre fragmenty gazet, zwłaszcza te historyczne, sprzed stulecia, zdaje się wykorzystywać z aprobatą, czego nie można powiedzieć o parodystycznie deformowanych fragmentach współczesnej radiowej audycji walentynkowej:

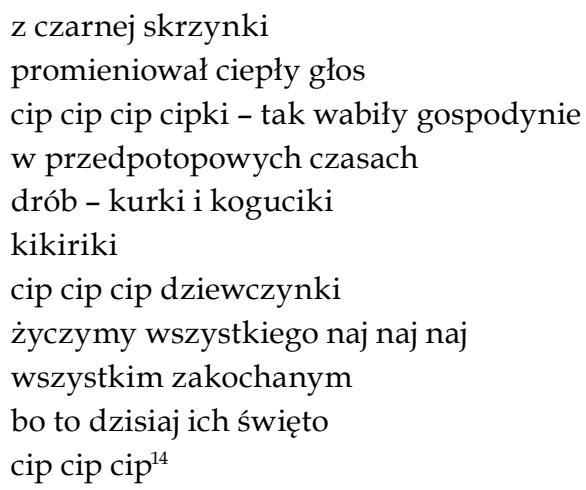

Niektóre elementy wypowiedzi dziennikarskiej (by przywołać jeszcze przykład z Tarczy) Różewicz poddaje z kolei zabiegom zupełnie wytrącającym słowo z przypisanych mu znaczeń; autor łączy informacje dotyczące

${ }^{12}$ T. Różewicz, jeszcze jeden dzień, [w:] to i owo..., s. 45. Jest to skreślony przez poetę fragment wiersza zachowany w jego rękopiśmiennej wersji umieszczonej w tomiku.

${ }^{13}$ T. Różewicz, Opowiadanie dydaktyczne, [w:] tegoż, Zawsze fragment, Wrocław 1996, s. 35.

${ }^{14}$ T. Różewicz, Walentynki, [w:] tegoż, zawsze fragment. recycling, Wrocław 1998, s. 41. 
różnych, oddalonych historycznie wydarzeń, okrawa je tak, by, niewiele znacząc, wskazywały jedynie na konkretne realia i - co więcej - kumuluje w jednej kolumnie przypominającej układ wersyfikacyjny:

\author{
Na Haiti spokój \\ W poszukiwaniu 11 ton skradzionych banknotów \\ Scotland Yard przeszukuje wszystkie lotniska \\ 16-letni morderca \\ Drzewo z okresu permu rośnie w Łodzi \\ Samoloty Luftwaffe nad Austrią \\ Arsenały jądrowe przestaną być tajemnicą ${ }^{15}$
}

Wszystkie te wycinki informacji - skumulowane, okrojone, odcięte od zdarzenia, które pierwotnie opisywały - stają się w istocie figurami informacji, bardziej niż na konkretne zdarzenia wskazują na schemat wiadomości prasowej czy właściwe jej techniki opisu rzeczywistości. A w szerszej perspektywie stają się rodzajem niebezpośredniej deklaracji, głosem podmiotu przytłoczonego ekspansywnym informacyjnym nadmiarem, który zaciera sens pojedynczego przekazu.

Bardziej bezpośrednią diagnozę obniżania wartości języka w tak zwanych współczesnych czasach postawił Różewicz w wierszu Słowa, z tomu Wyjście:

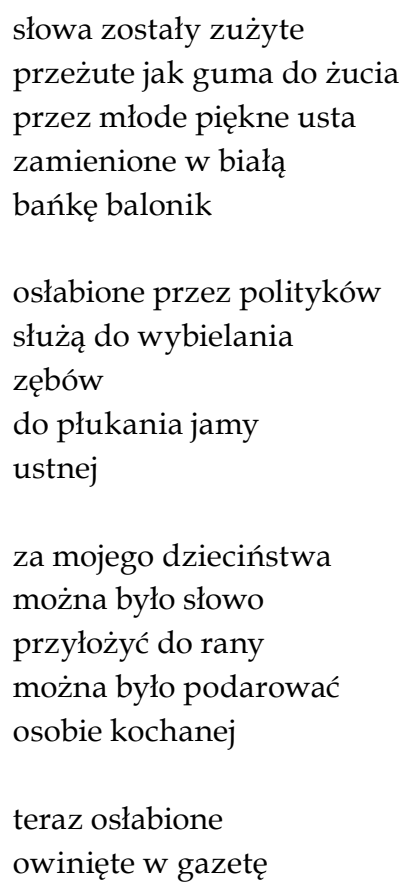

${ }^{15}$ T. Różewicz, Tarcza z pajęczyny, s. 244. 
jeszcze trują cuchną

jeszcze ranią

ukryte w głowach

ukryte w sercach

ukryte pod sukniami

młodych kobiet

zabijają $^{16}$

Nie stroni jednak poeta od "zużytych słów”, nie odcina się od nich na klasycystycznym parnasie, lecz przewrotnie zrównuje i łączy zdarzenia odmiennej rangi oraz przypisaną im mowę. Nie wynika to, rzecz jasna, z odczucia ich rzeczywistej równości, ale raczej z potrzeby demaskującego odzwierciedlenia globalnej znieczulicy, która wywołuje reakcje nieadekwatne do skali problemów i wydarzeń.

Poemat pod znamiennym tytułem recycling otwiera, sformułowana jako motto, niemiecka definicja tytułowej techniki obróbki, wzięta jakby z ekologicznej broszury. Odniesiona do utworu staje się metaforą przetwarzania słowa i zarazem literalnie pojmowaną obróbką opisanej w poemacie materii. Pierwsza część Moda, opatrzona w tytule również wymowną cezurą 1944-1994, łączy opisy ubrań noszonych przez obozowych więźniów z zapowiedziami współczesnych odzieżowych "trendów";

ona dostaje do męskiej koszuli

podarte kalesony

stare podarte spodnie

i bluzę z rosyjskiego żołnierza ${ }^{17}$

podczas gdy obok (w tekście)

w sportowych ubraniach

wracają do łask naturalne włókna

króluje wełna zmieszana

z poliestrami i poliamidami ${ }^{18}$

Te dwa porządki, opisane jako równoległe, celowo rażą kontrastem, choć jego ciężar równoważy pojawiająca się niespodziewanie między opisami spetryfikowana fraza $\mathrm{z}$ innego, celowo niestosownego tu porządku: „Pani spotka pana / Pani spotka panią".

${ }^{16}$ T. Różewicz, Poezja. Utwory zebrane, t. IV, Wrocław 2006, s. 217-218.

${ }^{17}$ Tamże, s. 41.

${ }^{18}$ Tamże, s. 40. 
Druga część poematu recycling, opatrzona ironicznie brzmiącą sentencją z Owidiusza, wiąże realia obozowe z aferami współczesnych banków przez drastycznie przedstawiony motyw przetwarzania złota:

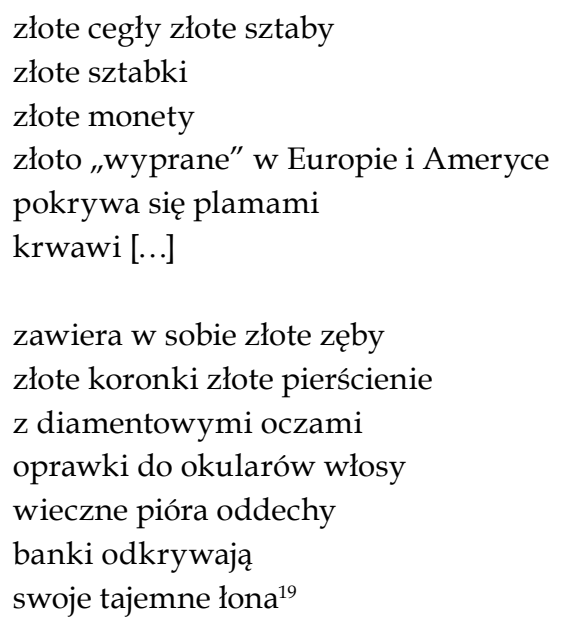

Znaczenia wypracowują się $\mathrm{w}$ wierszu między wyciszonym autorskim komentarzem a rwanymi fragmentami wypowiedzi z różnych porządków dyskursywnych: polska nota prasowa przechodzi w niemiecką, a po wymownych fragmentach Życia na niby Kazimierza Wyki zjawia się na prawach cudzego słowa antysemicki frazes.

Z kolei w trzeciej części poematu (Mięso) funkcję mowy obcej pełnią sformułowania na pozór neutralne. Wobec choroby szalonych krów, która stała się tematem wiersza (a właściwie: pretekstem do obnażenia dyplomatycznego pustosłowia), kolejne politycznie reprezentowane kraje „wyrażają ubolewanie”. Na skali globalnych emocji uplasowało się jeszcze zaniepokojenie i umiarkowane zdziwienie, $\mathrm{w}$ równej mierze zaradcze. Jak pisze autor $\mathrm{w}$ umieszczonym pod tą częścią komentarzu, ma ona „formę śmietnika (informacyjnego śmietnika), w którym nie ma centrum, nie ma środka. Zaplanowana jałowość i bezwyjściowość stała się głównym elementem składowym utworu..."20.

Podobnie pomyślany jest tomik Kup kota w worku, choć wszystkie wskazane wyżej problemy opracowania słowa już-gotowego w poetyckim recyklingu Różewicz przedstawia tu w najbardziej radykalnej postaci. Wypowiedzi wielu podmiotów wtapiają się $\mathrm{w}$ jeden wielorodny nurt narracji (notabene partii narracyjnych jest tu tak wiele, że trudno przesądzać o poetyckiej kwalifikacji książki, w katalogach bibliotecznych określanej jednak mianem tomiku poetyckiego). $\mathrm{W}$ pierwszych słowach utworu pojawia się głos w sprawie polszczyzny współczesnej:

\footnotetext{
19 Tamże, s. 45.

${ }^{20}$ Tamże, s. 65.
} 
w suwerennym kraju który odzyskał wolność w roku 1989 a teraz ma odzyskać wolność równość niepodległość zaczął zanikać panujący język polan - przepowiedzieli to zresztą zakichani futurolodzy lingwiści którzy stwierdzili że będą zanikały kolejno języki mniejszych plemion i grup etnicznych - na rzecz języka angielskiego jako języka globalnego i superjęzyka amerykańskiego ${ }^{21}$.

Narracja, na pozór poważna, stopniowo wyłamuje się z ram publicystycznej diagnozy, zwłaszcza przez słowo „zakichani”, celowo rażące stylistyczną odmiennością, ale też za sprawą powoli narastającego absurdu. W środku zdania, które zapowiada kontynuację tej - bądź co bądź - serio formułowanej wypowiedzi, nieoczekiwanie zmienia się jej podmiot: „W ten sposób proces zanikania mowy polskiej kurwa został przyspieszony i ten profesor Balcerczyk czy balcerowicz a nawet kochany miodek nie będzie miał nam co wytykać w języku polskim i musi mówić po amerykańsku sorry"22. Wypowiedź przeistacza się stopniowo w językową ilustrację założeń wywodu, by ostatecznie rozszczepić się na wiele głosów, które nadrzędny narrator kierujący wszystkimi cytowanymi mikrotekstami traktuje $\mathrm{z}$ jednakową ironią:

śniło mi się że z pustego nieba spadają czarne bociany a to były czarne meszki milimetrowe zaledwie muszki które zbierają się nad moim otwartym owocem kiedy on fermentuje [...] zgubiłam wątek ostrego erotyku z końca XIX wieku przerwa a więc fajnie kiedy kobieta omdlewa w objęciu, fajnie kiedy w lubieżnym zwisie przez ramię w zgięciu [...] gdy mi nagle zarzucasz nogi na ramiona wrzącej w żyłach rozkoszy czarem rozogniona gdy ręce moje węże oszalałe żądzą [...]. Zblanszuj cebulę weź trzy gruszki zrób segmenty z grejpfrutów ostrym nożem odetnij skórę na końcówkach owocu tak żeby widoczny był wilgotny miąż twojego łona postaw garnek na suficie i ruchem od góry do dołu odcinaj pozostały napletek razem z błonkami czuję że gubię wątek jak ten derrida albo jakiś nasz najlepiej sos przygotować w słoiku ementaler pokrój na zapałki²3.

Zapis absurdalnego snu przechodzi w relację z życia muszek, a potem w przedziwną opowieść, w której można rozpoznać głos młodej osoby (sądząc po znamionującej niedojrzałość specyficznej żarliwości jej wypowiedzi wtopionej w narrację), nieudolnie parafrazującej znany erotyk; mimo parodystycznej przesady można sobie wyobrazić realny przebieg takiej wypowiedzi i jej hipotetycznego nadawcę. A zatem, w pewnym sensie, narracja trzyma się reguł prawdopodobieństwa. Niespodziewanie jednak nakłada się na nią zupełnie inna opowieść, przedstawiająca fantazyjną, surrealną,

\footnotetext{
${ }^{21}$ T. Różewicz, Kup kota w worku (work in progress), Wrocław 2008, s. 7.

${ }^{22}$ Tamże.

${ }^{23}$ Tamże, s. 16.
} 
absurdalną wizję warzenia na suficie grapefruita $\mathrm{z}$ cebulą. Te dwie odmienne sekwencje różnych opowieści łączy przy tym wątek erotyczny, wywołany przez wiersz Przerwy-Tetmajera, i akcenty seksualno-anatomiczne z drugiej części fragmentu, która zresztą wydaje się interesująca nie tylko ze względu na kontrast tej surrealnej opowieści z relacją dziewczyny, ale też przez dającą się odtworzyć hipotetyczną historię swego powstania. Na przepis kulinarny, z natury rzeczy podporządkowany pragmatycznym funkcjom, lakoniczny i rzeczowy, pozbawiony poetyckiej inwencji, podmiot tej opowieści nakłada efekty groteski i wprawia statyczny obraz ukazanej w opisie przestrzeni w odrealniony ruch.

Tekstotwórcza strategia recyklingu redefiniuje znaczenie oryginalności. Wiąże się ona w przypadku Różewicza z inwencją łączenia gotowych tekstów, z twórczą ingerencją w ich postać, ze zmianą sensu użycia słowa, z nakładaniem na siebie kilku opowieści, z celowo nieadekwatnym wykorzystaniem środków literackich (we fragmencie, wobec którego są obce, jeśli wziąć pod uwage pierwotny kontekst ich użycia). Znaczenia konstytuują się tu w samej relacji łączącej wypowiedź źródłową z jej przetworzonym i zrekontekstualizowanym wariantem.

\section{Das Spiel mit den Möglichkeiten}

Twórczość Różewicza, rozpatrywana jako rozłożony na lata proces, uświadamia tendencję do intensyfikacji i kumulowania zjawisk najbardziej charakterystycznych dla jego poetyki. Jednym z nim jest (poza twórczym recyklingiem i wieloma innymi zjawiskami) zjawisko przeobrażania - niejako na oczach czytelnika - pojedynczych tekstów literackich. Andrzej Skrendo rozpatruje je jako grę, która polega na dopowiadaniu, uzupełnianiu, dopisywaniu dalszych ciągów ${ }^{24}$. Utwory, jak pisze, wędrują z książki do książki i nieustannie "odnajdują się" w nowych sąsiedztwach ${ }^{25}$. Tym samym "teksty Różewicza tworzą pewną «geometrię». Łączą się ze sobą za pomocą sieci odwołań i nawiązań, odbić i analogii, podobieństw i różnic; są powiązane za pomocą serii powtórzeń" 26 , a nie za pomocą ram autonomicznego tekstu.

Różewicz wznawia wydanie wielu utworów. Wiersze z tomu Niepokój, uznawanego za oficjalny debiut poety, ukazują się w 1947 roku, a potem, w całkiem innym układzie, w dwóch wydaniach wierszy zebranych. Uśmiechy, zbiór lekkich form prozatorskich, publikuje poeta trzy razy: w 1955, 1957 i 2000 roku. Inne zbiory rekomponuje bądź składa z drobnych tekstów wcześniej niepublikowanych lub rozproszonych w wielu książkach. Tym sposobem tomik Matka odchodzi z 1999 roku łączy tematy z publikowanego w zbiorach prozy dziennika gliwickiego, wiersze, które ukazywały się w różnych

\footnotetext{
${ }^{24}$ A. Skrendo, Przodem Różewicz, Warszawa 2012, s. 77.

${ }^{25}$ Tamże, s. 71.

${ }^{26}$ A. Skrendo Tadeusz Różewicz i granice literatury. Poetyka i etyka transgresji, Kraków 2002, S. 152.
} 
okresach twórczości, wspomnienia braci i dziennik matki, połączony z opisem tradycyjnych obyczajów wiejskich. W zbiorze znalazły się też fotografie, co czyni z niego przekaz ponadliteracki.

Graficzna strona tomików Różewicza zaczyna się z czasem rozwijać. Poza kopiami rękopisów, publikowanymi począwszy od wydanej w 1991 roku Płaskorzeźby, pojawiają się w nich również inne elementy wizualne, a więc grafiki artystów plastyków: Jerzego Tchórzewskiego ${ }^{27}$ czy Eugeniusza Geta-Stankiewicza, fotografie rozmaitych przedmiotów, luźno związanych z materią literacką, a także rysunki samego poety (Kup kota $w$ worku oraz to $i$ owo). Są zazwyczaj niezbyt czytelne, celowo niestaranne, niby-dziecięce. Sporo elementów graficznych wskazuje na prowokacyjną intencję przedstawienia niewiele znaczących elementów codziennej rzeczywistości. Poeta układa z nich kompozycje, których na pierwszy rzut oka nie tłumaczy żaden porządek (poza dziełem przypadku), na przykład umieszcza w samym rogu stronicy wykrojony fragment ilustracji zachowującej odręczny zapis wiersza, co istotne: $\mathrm{z}$ kilku stron ścięty. Trudno cokolwiek w nim odczytać; literalne znaczenia są nieczytelne. Jej sens ujawnia perspektywa metaartystyczna. Wycinek ilustracji zdaje się wykraczać poza granice książki, funkcjonuje jako część niewidocznej całości, a więc oddaje na poziomie wizualnym zachowany $\mathrm{w}$ warstwie literackiej sens istnienia utworu poza granicami wyznaczanymi przez formy i struktury dzieła artystycznego.

Innym przykładem intersemiotycznej uniwersalności sformułowanych przez Różewicza koncepcji artystycznych jest fotografia papierka po cukierku "Makbet”, podpisana słowami: „moja inscenizacja Makbeta”. Znaczenie ilustracji nie wyczerpuje się $w$ formule żartu czy kpiny $z$ wysokoartystycznych aspiracji inscenizacyjnych. Oto wizualny wariant artystycznego recyklingu, w rzeczy samej element śmietnika, uwzględniony w utworze ze względu na karnawałowe zrównanie "góry" z "dołem”, sztuki wysokiej z pozostałością po zwykłym cukierku. $Z$ pewnością wszystkie późne tomiki Różewicza są starannie przemyślanym projektem graficznym. Ostatnie dwa zbiory wierszy, wymownie zatytułowane Kup kota w worku (work in progres) (2008) oraz to $i$ owo (2012), należałoby $\mathrm{w}$ zasadzie określić mianem opublikowanych w formie książek instalacji wierszowo-plastycznych, również ze względu na graficznie wyeksponowaną procesualność tworzenia. Co istotne, ilustracje dołączane przez poetę do tomików nie są podrzędne względem materii literackiej, nie występują $\mathrm{w}$ funkcji „konkretyzacji warstwy przedmiotowej dzieła", by przywołać termin wprowadzony do badań nad relacjami między tekstem a obrazem przez Sewerynę Wysłouch ${ }^{28}$. Są to raczej ilustracje równorzędne i autonomiczne względem tekstu; badaczka traktuje tego typu obiekty wizualne włączone do książki jako "przekład intersemiotyczny”.

${ }^{27}$ Już w Płaskorzeźbie, a nawet wcześniej, w jednym z wydań Przygotowania do wieczoru autorskiego.

${ }^{28}$ Funkcja konkretyzacji służy nadaniu przedstawionym $w$ utworze literackim przedmiotom cech jednostkowych przez wzbogacenie ich o jakości wizualne. S. Wysłouch, Literatura a sztuki wizualne, Warszawa 1994, s. 101. 
Można powiedzieć, objaśniając tu znaczenie tego terminu i odnosząc go do omawianej twórczości, że w późnych tomikach Różewicza „ilustrator [czyli $\mathrm{w}$ tym przypadku sam autor - M.B.], pragnąc zrekonstruować tekst $\mathrm{w}$ innym tworzywie, przekłada znaki literackie na sztukę wizualną" ${ }^{29}$, poszukuje plastycznego ekwiwalentu dla sensów konotowanych przez świat przedstawiony ${ }^{30}$, w postaci obrazów, które nie tylko oznaczają, ale też znaczą i przekładają poza fabułą również zjawiska niefabularne, takie jak postawy, oceny czy nastrój $j^{31}$.

Z czasem Różewicz zaczyna prezentować rękopiśmienne warianty swoich utworów z mniejszą konsekwencją (niż na przykład w bliźniaczych wersjach wierszy w Płaskorzeźbie), ale jednocześnie czyni to w bardziej różnorodny sposób. W Nożyku profesora wydanym w 2001 roku tylko do części wierszy dodaje ich rękopiśmienny wariant. Prezentuje przy tym różne stadia procesu twórczego. Czytelnik widzi zarówno pierwotne wersje tekstów, które przyjmują formę pokreślonych szkiców, jak i przykłady kopii wariantów drukowanych, na które poeta nanosi poprawki, na przykład sześcioma długopisami - jak w tytułowym poemacie. Dopisek uwzględniony w owej rękopiśmiennej wersji Nożyka zdradza, że utwór powstawał pół wieku, od 1950 roku. Wszystkie te okoliczności, które ujawnia graficzna postać wiersza, rzucają pewne światło na poruszoną w tekście problematykę pamięci i wyrażalności doświadczeń granicznych.

Rękopisy publikowane $\mathrm{w}$ tomikach były przedmiotem wielu rozpraw ${ }^{32}$. Zmierzają one na ogół do analizy reguł wykreślania i zamazywania, skoncentrowanej wokół problematyki krystalizowania się znaczeń w konkretnych fragmentach pojedynczych utworów. Metaliterackie konsekwencje takiego eksponowania procesualności tworzenia nie były raczej przedmiotem analiz. Tymczasem warto rozważyć, na ile publikacja rękopisów wynika z potrzeby prezentowania procesu twórczego i w jakim stopniu gest ich uwzględnienia stanowi kierowany do czytelnika znaczący przekaz, tłumaczący się jako element koncepcji złożonego, procesualnie ujmowanego dzieła literackiego, którego sens wykracza poza formułę efektu pracy twórczej. Zwraca na to uwagę Maria Prussak w swojej interpretacji tomiku Nożyk profesora. Jak pisze badaczka - za Januszem Drzewuckim - rękopisy i maszynopisy nie są dokumentami pracy ${ }^{33}$. Funkcjonują już bowiem jako autorska publikacja,

\footnotetext{
${ }^{29}$ Tamże, s. 119.

30 Tamże, s. 138.

${ }^{31}$ Tamże.
}

${ }^{32}$ A. Skrendo, Tadeusz Różewicz i granice literatury. Poetyka i etyka transgresji, Kraków 2002; T. Kunz, Strategie negatywne w poezji Tadeusza Różewicza. Od poetyki tekstu do poetyki lektury, Kraków 2005; S. Jaworski, „Piszę, więc jestem”. O procesie twórczym w literaturze, Kraków 1993; R. Przybylski, Baśń zimowa. Esej o starości, Warszawa 2008; T. Wójcik, Skreślone słowa Tadeusza Różewicza (archeologia rękopisów), [w:] (Nie)obecność. Pominięcia i przemilczenia w narracjach XX wieku, red. H. Gosk, B. Karwowska, Warszawa 2008; T. Kłak, Liryki lozańskie Tadeusza Różewicza, [w:] tegoż, Reporter róż. Studia i szkice literackie, „Śląsk”1978.

${ }^{33}$ Zob. J. Drzewucki, Róża, róża i rdza, „Twórczość” 2001, nr 10, s. 109. Cyt. za: M. Prussak, "Robigus zjada żelazny nożyk", "Teksty Drugie” 2014, nr 3, s. 61. 
prezentują jeden z wielu niepublikowanych wariantów, a co więcej mogą być częścią autorskiej kreacji ${ }^{34}$. Skreślenie nie jest znakiem nieistnienia, wręcz przeciwnie, stanowi środek intensyfikujący spojrzenie czytelnika, powoduje, że słowo przekreślone wybija się w językowej i znaczeniowej warstwie wiersza. Maria Prussak podkreśla, że „pisarz z premedytacją steruje uwagą czytelnika, który tym bardziej intensywnie wpatruje się w słowa, im mniej czytelny jest zapis" ${ }^{\prime 35}$. Tomik poety traktuje badaczka jako wielowarstwową konstrukcję, w której istotną rolę odgrywają równoległość przekazu i wielopłaszczyznowość informacji ${ }^{36}$. Przytaczając słowa poety, dowodzi również istoty pomijanej $w$ analizach tomiku materialności i graficzności utworów: „U mnie zaś budowa, konstrukcja, montaż utworu, że się tak wyrażę w języku filmu, odgrywały często rolę decydującą. Przesunięcie kilku słów czy złamanie wersu było dyktowane nie tylko składnią lub logiką, ale również kształtem graficznym utworu, jego logiką plastyczną. Moje wiersze to nie tylko myśli i pojęcia, ale również rzeczy namacalne, sensualne" ${ }^{\prime 37}$. Zdaniem Marii Prussak nie sposób rekonstruować procesu twórczego Różewicza śladem badaczy ze szkoły genetycznej. Trudno polemizować z tą konstatacją, choć odniesienie tej twórczości do założeń francuskich badaczy może rzucić pewne światło na jej specyfikę.

Szkoła genetyczna praktykuje analizę niepublikowanych materiałów będących częścią pracy nad wydanym tekstem. Zgodnie z jej nomenklaturą określa się je mianem przed-tekstu, który - ściślej mówiąc - oznacza „całość utworzoną przez bruliony, rękopisy, korekty, warianty, widziane z punktu widzenia tego, co poprzedza materialne dzieło, gdy jest ono traktowane jako tekst, i która może tworzyć system z tekstem" ${ }^{38}$, by przywołać słowa Jeana Bellemin-Noëla. Samo pojęcie tekstu (niezbyt operacyjne w odniesieniu do poetyki późnych tomików Różewicza) jest w tej perspektywie badawczej zasadnicze, stanowi oś oddzielającą porządek materiału literackiego opracowywanego w procesie twórczym i porządek opublikowanych wariantów utworu, czyli genetykę rękopisów i genetykę druków, mówiąc językiem tej szkoły. Jak pisze Pierre-Marc de Biasi:

Dzieło literackie, dopóki istnieje $\mathrm{w}$ formie rękopisu [...], zawsze jest narażone na ryzyko radykalnych zmian albo na unicestwienie. To właśnie patrzenie $\mathrm{z}$ perspektywy jego przemiany $\mathrm{w}$ wersję drukowaną pozwala określić jako „ostateczne” te końcowe rękopiśmienne etapy dzieła, które publikacja utrwala w formie (prowizorycznie) niezmiennej, którą odtąd można nazywać tek s te m dzieła. Wszystko, co znajdzie się przed tą linią

\footnotetext{
${ }^{34}$ M. Prussak, „,Robigus..., s. 61.

${ }^{35}$ Tamże, s. 65.

${ }^{36}$ Tamże.

${ }^{37}$ A. Sapija, Jak powstat "Nożyk profesora”, [w:] Wbrew sobie. Rozmowy z Tadeuszem Róźewiczem, oprac. J. Stolarczyk, Wrocław 2011, s. 362, cyt. za: M. Prussak, „Robigus..., s. 64.

${ }^{38}$ Cyt. za: S. Jaworski, „Pisze, więc jestem..., s. 89.
} 
podziału, należy do dziedziny przed-tekstu i pozwala obserwować ge netykę rękopisów (albo genetykę przed-tekstu), a wszystko, co znajduje się za nią, należy do dziedziny tekstu i pozwala obserwować g en et ykę druków (albo historię powstania tekstu) ${ }^{39}$.

Krytyka genetyczna różni się od tradycyjnej tekstologii postrzeganiem roli materii literackiej powstałej przed drukiem. Tekstologia traktuje ją jako ogół dokumentów służebnych wobec wydawanego utworu i zmierza do ustalenia ostatecznej wersji tekstu. Krytyka genetyczna uznaje materiały przed-tekstu za elementy całościowo postrzeganego procesu twórczego, komplementarne wobec tekstu. Badacze z tego kręgu unikają więc takich pojęć, jak poprawka czy wersja ${ }^{40}$. "Skreślić - pisze Bellemin-Noël - to nie znaczy usunąć jakiś zbędny szczegół, lecz: «zastąpić, przekształcić». Gest skreślenia jest więc także "gestem pisania», nadawania znaczenia".

Klaus Hurlebusch, inny badacz z kręgu krytyki genetycznej, definiował perspektywę swojej szkoły badawczej w odniesieniu do strukturalizmu. Zwracał uwagę na zmianę pola obserwacji, która polega na przesunięciu akcentu: „od tekstu jako zamkniętego wytworu semiotycznego do produkcji tekstów”, „od napisanego („l'écrit”) do pisania („l'écriture”), od druku do rękopisów" ${ }^{\prime 1}$. Poetyka późnych tomików Różewicza pod wieloma względami bliska jest tej problematyce, choć zarazem w jednej zasadniczej kwestii odcina się od francuskiej szkoły badawczej. Istotnie, wiersze z tomików to i owo, Kup kota w worku, Nożyka profesora czy Płaskorzeźba bliższe są koncepcji otwartego tworzenia tekstów niż modelowi tekstu pojętego jako zamknięta semiotyczna całość; większy nacisk kładą na pisanie niż ostateczną postać napisanego. Należy przy tym podkreślić, że podmiotem ujawniającym porządek przed-tekstu jest w genetycznej analizie dzieła badacz, a w opisywanych tu tomikach - sam autor. Te dwa przypadki zakładają inny typ lektury. Francuscy badacze prezentują czytelnikowi materię literacką w oderwaniu od podmiotowej autorskiej intencji, tym samym narzucając perspektywę zewnętrzną wobec scenariusza odbioru wpisanego w sens dzieła. Przed-tekst Różewicza jest natomiast częścią tekstu, uznaną przez niego i uprawomocnioną materią poetycką. Autor Nożyka profesora wyprowadza skończony tekst poza jego granice, cofa go do fazy przedtekstowej, a tym samym traktuje proces twórczy jako zjawisko nie mniej istotne niż sam utwór.

Za inny ważny dla wskazanej tu problematyki kontekst można uznać koncepcje spójności tekstu literackiego. Przedstawia je Włodzimierz Bolecki w tekście Spójność tekstu (literackiego) jest konwencją, by określić własną teorię spójności w polemicznym odniesieniu do założeń poprzedników, głównie Marii Renaty Mayenowej. Badacz formułuje w tym kontekście trzy zasadnicze pytania: czy kategoriami tekstu są zdania, czy ma on własne kategorie

\footnotetext{
${ }^{39}$ P.M. de Biasi, Genetyka tekstów, przeł. F. Kwiatek, M. Prussak, Warszawa 2015, s. 50.

${ }^{40}$ Z. Mitosek, Krytyka genetyczna, [w:] tejże, Teorie badań literackich, Warszawa 1995.

${ }^{41}$ Cyt. za: tamże, s. 93.
} 
tekstowe? Czy spójność dotyczy tylko wpisanych w tekst elementów językowych, czy również obejmuje sferę presupozycji, pozatekstową wiedzę czytelnika? Czy elementy metatekstowe są strukturalnym elementem tekstu? ${ }^{42}$ Pytania wynikają z kwestii omówionych przez Mayenową. Badaczka traktuje tekst jako sumę linearnie przyrastających ciągów wielozdaniowych, przyjmuje, że tekst spójny ma jeden temat, jednego nadawcę i jednego odbiorcę, że cechuje się formą homogeniczną, w której nie mieszczą się elementy metatekstowe czy dialogi, zależy od spełnienia normy językowej, a „funkcja poetycka odgrywa rolę destruktora spójności tekstu".

Autor artykułu zwraca uwagę, że założenia Mayenowej „,są dla tekstów literackich nieswoiste" ${ }^{\prime 3}$. Skoncentrowane na ściśle językowym pojęciu zdania nie znajdują uzasadnienia jako narzędzia analizy tekstu literackiego, który wymaga wypracowania właściwych mu kategorii opisu. W opisie spójności tekstu literackiego nie ma większego znaczenia linearna ciągłość zdań. Ważne jest natomiast myślenie o dziele w kategoriach struktury, analiza relacji między różnymi jej poziomami (na przykład narracją a fabułą, dialogiem a narracją, leksyką a symboliką układów ponadzdaniowych) ${ }^{44}$; wedle badacza, w dziele literackim to właśnie one, a nie kategorie syntaktyczne decydują o spójności tekstu. Podkreśla on również, że spójność to problem lektury; nielinearne sensy wiąże w całość interpretacja.

Przypadek Tadeusza Różewicza jest tu o tyle interesujący, że jego twórczość wykracza nawet poza tak szeroko zdefiniowane ramy spójności. Jednocześnie widziana jako całość - obejmująca sumę utworów (które wciąż odkrywczo wykorzystują te same chwyty czy rozwiązania) i konsekwentnie rozbudowywanej metaliterackiej koncepcji - jest koherentna. Jak zdefiniować mechanizm spójności utworów Różewicza? Dwie przedstawione wyżej koncepcje omawianej problematyki skoncentrowane są na kategoriach zdania i tekstu, które w odniesieniu do tej twórczości nie są operacyjne. Myślenie o spójności dzieła literackiego w kategoriach składni nie jest właściwe dla jego analizy, jeśli zgodzić się z konstatacją Boleckiego. Tekst z kolei traci w dziele Różewicza swoje granice, nie tworzy trwałej ramy stabilizującej znaczenia utworu i jego formalną postać. Poeta umniejsza znaczenie samego tekstu, czyniąc z jego wyłamanych granic znak odrzuconej struktury, a na czoło wysuwa same relacje i problematyzowane kategorie literackie. Co ciekawe, są one tutaj nie tylko presuponowane, ale też wpisane w znaczeniowy i formalny obszar dzieła, stanowią temat sam w sobie. Ramy spójności wyznacza w utworach poety nie zdanie i nie tekst, lecz dorobek, w którym rozproszone są metaliterackie znaczenia Różewiczowskiej literatury.

Warto tu jeszcze powrócić do zarysowanej we wstępie koncepcji zamiennika gatunkowego i - w perspektywie omówionej nieco szerzej metaliterackiej

${ }^{42}$ W. Bolecki, Spójność tekstu (literackiego) jest konwencja, [w:] Teoretycznoliterackie tematy i problemy, red. J. Sławiński, Wrocław, Warszawa, Kraków, Gdańsk, Łódź 1986, s. 159.

43 Tamże, s. 165.

44 Tamże, s. 170. 
wizji poety - rozważyć, czy sama nazwa kategorii sformułowanej przez Kazimierza Wykę, odniesiona zwłaszcza do późnych tomików Różewicza, nie zawęża zanadto obszaru problematyki, którą można z nich wyprowadzić. Rozwój twórczości późniejszej względem rozpoznań Kazimierza Wyki uzasadnia być może szersze zastosowanie koncepcji jej procesualnego ujmowania. Słowo „zamiennik" skupia uwagę na aspekcie zastępowania jednej formy przez inną, określenie "gatunkowy" odnosi problem do sfery genologicznej. Można uznać, że wskazany przez badacza mechanizm dotyczy również innych porządków i struktur, w jakich może istnieć dzieło literackie. Ponadto obejmuje ono swoim zakresem więcej zjawisk niż czynność zastępowania. Poza wskazanymi przez Kazimierza Wykę intencją, jej wykonaniem i rozmyciem szeroko pojęte dzieło Różewicza wiąże w jedną całość również paralelnie istniejące warianty i proces twórczy - w pewnej mierze uchwycony, ale też istniejący potencjalnie, wykraczający poza próby jego zapisu ${ }^{45}$. Obejmuje też wskazane przez Tomasza Kunza napięcia, relacje, funkcjonalne współistnienie poszczególnych składników, w ostatnich tomikach niejako wpisane w semantyczną strukturę zdublowanych wierszy, synchronicznie ujęte w dorobku pojmowanym przez badacza jako przekaz wielotekstowy ${ }^{46}$. Dzieło Różewicza obejmuje również zjawiska, które autor usuwa, z rozmysłem zachowując ich widoczne ślady: zamazania i skreślenia czy fragmenty struktur i form, których czytelnik mógłby oczekiwać, a których celowo zabrakło. Na dzieło literackie (a może szerzej: artystyczne?) składają się wreszcie różnego typu elementy wizualne. Wszystkie znaki zaniechania, „rozmycia pierwotnego zamierzenia” i niezgodności z normą mają $\mathrm{w}$ tych szeroko zakreślonych ramach dzieła sens metaliteracki; pozwalają testować granice literatury i redefiniować zakres możliwych jej postaci. Dzieło literackie Różewicza to zatem suma procesów, śladów, zaniechań i wariantów tekstu, w równym stopniu znaczących, a wiąże je dająca się wyprowadzić z różnych zapisków autorska koncepcja literatury.

Sam autor przedstawia swoją wizję jako nieogarnięty ramą jednego manifestu czy programu poetyckiego zbiór przypadków, wyjątków, pojedynczych rozwiązań niemających kontynuacji w obrębie pojedynczego utworu. Rodzi to pytanie: czy w interpretacji metaliterackiej koncepcji Różewicza i samych realizujących ją utworów należy kierować się poetyką samych tekstów, skupiając uwagę na opisie fragmentarycznych idei? Czy może przeciwnie - do literackich tendencji i upodobań poety podejmować niejako na przekór niemu „próbę całości” i rekonstruować jego koncepcję jako spójny system? Być może byłaby to (albo jest) uzurpacja, choć z drugiej strony: czy proces odczytywania sensów na poziomie lektury musi ściśle odpowiadać procesowi ich konstruowania w pracy twórczej? Metaliterackie idee wciąż powracają w twórczości Różewicza. Formułowane podobnie, tworzą system reguł. Ich konsekwencja i spójność pozwala przychylić się do próby całościowego ujęcia

${ }^{45}$ Autor publikuje w ostatnich tomikach "tylko" dwa warianty spośród kilkunastu istniejących, jak deklarował w wielu wywiadach. Zwraca na to uwagę Maria Prussak w cytowanym tu już artykule Robigus zjada żelazny nożyk.

${ }^{46}$ T. Kunz, Strategie negatywne..., s. 169. 
wizji literatury, a w rozproszeniu sensów widzieć nie tylko dynamikę stopniowego wypracowywania metaliterackiej koncepcji, rozłożonego w sześćdziesięcioletnim okresie twórczości, ale również wskazówkę wielokierunkowej, skontekstualizowanej, nielinearnej lektury, pozwalającej zarówno wiązać ze sobą rozmaite idee tej metaliterackiej koncepcji, jak i widzieć w nich symptomatyczne znaki kultury współczesnej.

\section{B I B L I O G R A F I A}

Biasi P.M. de, Genetyka tekstów, przeł. F. Kwiatek, M. Prussak, Warszawa 2015. Bolecki W., Pre-teksty i teksty. Z zagadnień zwiazków międzytekstowych w literaturze polskiej XX wieku, Warszawa 1998.

Bolecki W., Spójność tekstu (literackiego) jest konwencją, [w:] Teoretycznoliterackie tematy i problemy, red. J. Sławiński, Wrocław, Warszawa, Kraków, Gdańsk, Łódź 1986.

Bukowiecka M., "Tarcza z pajęczyny” z daleka i z bliska. Intertekstualność kolażu literackiego, [w:] Projekt na daleka metę. Prace ofiarowane Ryszardowi Nyczowi, red. Z. Łapiński, A. Nasiłowska, Warszawa 2016.

JaworskiS., ",Piszę, więcjestem”. O procesie twórczym w literaturze, Kraków 1993.

Kunz T., Strategie negatywne w poezji Tadeusza Różewicza. Od poetyki tekstu do poetyki lektury, Kraków 2005.

Mitosek Z., Krytyka genetyczna, [w:] Z Mitosek, Teorie badań literackich, Warszawa 1995.

Prussak M., „Robigus zjada żelazny nożyk”, „Teksty Drugie” 2014, nr 3, s. 61.

Różewicz T., Dramat. Utwory zebrane, Wrocław 2005.

Różewicz T., Kup kota w worku (work in progress), Wrocław 2008.

Różewicz T., Poezja. Utwory zebrane, Wrocław 2006.

Różewicz T., Proza. Utwory zebrane, Wrocław 2003.

Różewicz T., To i owo, Wrocław 2012.

Różewicz T., Zawsze fragment, Wrocław 1996.

Różewicz T., Zawsze fragment. Recycling, Wrocław 1998.

Skrendo A., Przodem Różewicz, Warszawa 2012.

Skrendo A., Tadeusz Różewicz i granice literatury. Poetyka i etyka transgresji, Kraków 2002.

Wyka K., Problem zamiennika gatunkowego, [w:] K. Wyka, Różewicz parokrotnie, oprac. M. Wyka, Warszawa 1977.

Wysłouch S., Literatura a sztuki wizualne, Warszawa 1994. 


\section{STRESZCZENIE}

Artykuł poświęcony jest analizie twórczości Tadeusza Różewicza, rozpatrywanej ze względu na zagadnienie spójności tekstu. Utwory Różewicza sprawiają wrażenie otwartych w tym sensie, że nie zamykają się w jednej formie, którą można by uznać za ostateczną, ale wciąż ewoluują, publikowane w kolejnych tomikach lub w dwóch równolegle drukowanych wersjach, rękopiśmiennej i sprawiającej wrażenie ostatecznej. Autor wykracza w swojej twórczości poza ramy gatunków literackich czy stylu artystycznego, a także poza sferę tekstu, którą można zidentyfikować z jego głosem, i twórczo wykorzystuje elementy gotowych wypowiedzi użytkowych. Pozwala to wskazać w jego twórczości dominację dwu strategii tekstotwórczych: eksponowaniu procesualności tworzenia i literackiego recyklingu polegającego na eksperymentalnym przetwarzaniu języka nieartystycznego. Utwory Różewicza, pozornie otwarte, labilne i nietrwałe, $w$ istocie tworzą jednak całościową i spójną koncepcję literackości. Trudno ją uchwycić w analizie pojedynczego utworu czy nawet całego tomiku, tę właściwość pisarstwa Różewicza ujawnia całościowe spojrzenie na jego dorobek. Znaczenia $\mathrm{w}$ jego utworach formują się nie tyle w obrębie pojedynczego tekstu, ile między różnymi jego wariantami, a więc znaczące są tu i teksty, i łączące je relacje. Otwierając kompozycję swoich utworów, Różewicz projektuje lekturę wielokierunkową, skontekstualizowaną, równoległą i zespajającą rozproszone w całym dorobku wersje utworu w jedną złożoną całość. Sankcjonuje tym samym swój otwarty warsztat pracy nad tekstem jako metaliteracki problem, przedmiot reprezentacji i zarazem integralny składnik utworu literackiego, a samo dzieło traktuje jako dynamiczny proces, a nie strukturę zamkniętą w scalających utwór formach. Teoretycznym punktem odniesienia moich rozważań jest koncepcja zamiennika gatunkowego Kazimierza Wyki, koncepcje spójności tekstu Marii Renaty Mayenowej i Włodzimierza Boleckiego oraz założenia krytyki genetycznej.

\section{Słowa kluczowe}

Tadeusz Różewicz, spójność tekstu literackiego, proces twórczy, recykling literacki

\section{SUMMARY}

\section{Literary Work as a Process. On the Coherence of Texts by Tadeusz Różewicz}

The purpose of this article is to analyse works by Tadeusz Różewicz in terms of text coherence. Różewicz's writings seem to be open in the sense that they do not close within one form which could be recognised as the final form. Instead, they keep evolving, published in consecutive volumes or two simultaneous printed versions - handwritten and seemingly final. In his output, Różewicz goes beyond the framework of literary genres and artistic style, and also beyond the sphere of text which could be identified by his voice, as he creatively uses ready-made functional forms. This makes it possible to show two dominant text-generating strategies in his works: 
exhibiting the processuality of creation and literary recycling, which are both based on the experimental processing of non-artistic language. Różewicz's works - seemingly open, labile and undurable - do form, in fact, a holistic and coherent conception of literariness, which is difficult to perceive through the analysis of a single work or even the whole collection of poems, but is revealed upon a holistic look at his literary output. In his works, meanings are not formed within a single text, but between its various variants, and thus, both texts and the relationships between them are crucial here. Opening the composition of his works, Różewicz projects multidirectional reading, contextualised, simultaneous and joining all dispersed versions of any given work into one complex unity. This is how he also legitimises his open technique of working on text as a metaliterary issue, an object of representation and, at the same time, an integral constituent of a literary work, and the work itself he treats as a dynamic process and not a structure closed within the forms that integrate the work. The theoretical point of reference for my studies is the concept of genre substitute coined by Kazimierz Wyka, the conception of text cohesion by Maria Renata Mayenowa and Włodzimierz Bolecki, and assumptions of genetic criticism.

\section{Keywords}

Tadeusz Różewicz, cohesion of literary text, creative process, literary recycling 